\title{
Sex hormones and acid gastric secretion induced with carbachol, histamine, and gastrin
}

\author{
B. O. AMURE AND A. A. OMOLE \\ From the Department of Physiology, University of Ibadan, Ibadan
}

SUMMARY This study confirms previous reports that satisfactory gastric acid secretory responses to intravenous administration of histamine, carbachol, and gastrin can be obtained.

Bilateral castration of the male rats significantly reduced acid gastric secretory responses to carbachol but not to histamine.

Ovariectomized rats treated with $17 \mathrm{~B}$-oestradiol (short-term treatment) showed a statistically significant reduction in gastric acid secretion induced with all the secretagogues, but the results when rats were treated with testosterone were inconsistent. In animals given gastrin or histamine gastric acid secretion was reduced and was of statistical significance with gastrin $(0.02<$ $\mathrm{P}<0.05)$ but not with histamine $(0.05<\mathrm{P}>0.1)$.

It is concluded that a high oestrogen blood level is capable of inhibiting effectively acid gastric secretion in both sexes except that a higher level of blood oestrogen is required in the male. The results showed further that of all the sex hormones used, only oestrogen had a significant effect on gastric acid secretion.

It has long been recognized that peptic ulceration rarely occurs in human pregnancy. This has naturally focused attention on gastric secretory activity during this period, and there have been reports of diminished secretion of pepsin and hydrochloric acid during pregnancy (Artz, 1930; Strauss and Castle, 1932; Labate, 1939; Way, 1945; Murray, Erskine, and Fielding, 1957; Hunt and Murray, 1958). In the dog no consistent change in acid gastric secretion was found during pregnancy (McCarthy, Evans, and Dragstedt, 1954; Clark, 1957) while pregnant rats showed a significant reduction (Lozzio, Gagliardi, Biempica, and Royer, 1961). Since high blood levels of female sex hormones and chorionic gonadotrophins occur in pregnancy, a link between the hormones and acid gastric secretion has been sought experimentally and clinically (Ojha and Wood, 1950; MacDonald, 1956; Ghosh, 1959; Kaufmann and Spiro, 1968). There are several Received for publication 9 December 1969. reports that oestrogens hasten the healing of peptic ulcers in man (Truelove, 1960; Doll, Hill, and Hutton, 1965; Parbhoo and Johrston, 1966) and that these hormones also significantly reduce the acid secretory responses to histamine in cats (Ojha and Wood, 1950). In the rat (Ghosh, 1959) and dog (Culmer, Atkinson, and Ivy, 1939) chorionic gonadotrophins have been shown to inhibit acid gastric secretion.

Previous work on cats has shown that, compared with the female animal, the male animal exhibits a significantly higher gastric secretory activity in response to histamine (Ojha and Wood, 1950), and there was also a report (Baron, 1963) that women secrete less acid than men. It is not unlikely, therefore, that gonadal secretions in animals have physiological effects on acid gastric secretion.

The aim of this work was to assess the influence of the male and female sex hormones on acid gastric secretion in rats of both sexes. 


\section{Methods}

Adult rats of albino and hooded strains of both sexes weighing 200-380 g were subjected to bilateral gonadectomy under light ether anaesthesia. Some seven to 21 days after gonadectomy the rats were treated with sex steroids in oil suspension.

\section{OESTROGEN AND PROGESTERONE}

ADMINISTRATION

Castrated male rats (orchidectomized) were given oestrogen (17 B-oestradiol, Sigma Chemical Company) in two groups. One group of 13 rats received short-term oestrogen treatment which consisted of subcutaneous injections of $60 \mu \mathrm{g}$ of 17B-oestradiol daily given in two well spaced doses of $30 \mu \mathrm{g}$ for four days. The first dose was given at 8 am and the second dose 12 hours later. The second group of animals on long-term treatment received $120 \mu \mathrm{g} 17 \mathrm{~B}$-oestradiol by subcutaneous injection in doses of $60 \mu \mathrm{g}$ twice daily for nine to 11 days.

Fourteen gonadectomized female rats (ovariectomized) were subjected to the short-term $17 \mathrm{~B}$ oestradiol treatment. Another group of 14 ovariectomized rats was given progesterone (Progestin, BDH Ltd) in daily doses of $4 \mathrm{mg}$. Progesterone was given intramuscularly in two doses of $2 \mathrm{mg}$ each for four days.

\section{TESTOSTERONE ADMINISTRATION}

Thirteen ovariectomized rats were given testosterone ( $\Delta^{4}$-Androsten-17B-1-3-one, Sigma Chemical Company) in a dose of $2 \mathrm{mg}$ given in intramuscular injections of $1 \mathrm{mg}$ twice daily for four days.

For the purpose of the experiments, the animals used included normal uncastrated rats; castrated male rats treated with sex hormones; castrated rats not treated with sex hormones; normal female rats; ovariectomized female rats treated with sex hormones; and ovariectomized rats not treated with sex hormones. All the animals were tested for acid gastric secretion studies. The rats were anaesthetized with $25 \%$ $\mathrm{w} / \mathrm{v}$ urethane, $0.6 \mathrm{ml} / 100 \mathrm{~g}$ body weight given intramuscularly, and the stomachs prepared for perfusion with $0.00025 \mathrm{~N}$-sodium hydroxide solution as described by Ghosh and Schild (1958) and by Amure and Ginsburg (1964). The $p \mathrm{H}$ of the gastric effluent fluid was recorded continuously by a direct reading $p \mathrm{H}$ meter and registered graphically on an ink recorder.

Gastric acid secretion was induced by histamine dihydrochloride, carbachol, and gastrin injected intravenously via a cannulated femoral vein. The doses of histamine ${ }^{1}$ were expressed in $\mu \mathrm{g}$ of the salt; carbachol ${ }^{2}$ doses were expressed in nanograms. Partially purified hog gastrin powder was supplied by Ginsburg (Chelsea College of Science and Technology, London). Gastrin activity was measured in units of the partially purified extract, and a unit activity was found to be equivalent to 50 nanograms of gastrin II. A fall in the $p \mathrm{H}$ of the gastric effluent was a measure of acid gastric secretory responses. The response metameter chosen was the maximum fall in $p \mathrm{H}$ of the gastric effluent after the injections. The doses of secretagogue which caused a unit fall in the $p \mathrm{H}$ of the gastric effluent fluid were determined from the log dose-response diagrams which were linear in all experiments with graded doses of secretagogues. This value expressed per $100 \mathrm{~g}$ body weight was the chosen index of the gastric secretory response. Increases in the value above control levels were interpreted as a reduction of acid secretory activity by the stomach. In all experiments, the normal rats were used as the controls for the castrated untreated rats while the castrated untreated rats in turn served as controls for the castrated hormone-treated rats. Student's $t$ test was used to assess significance.

Oestrogenic effects, such as the enlargement of the mammary glands, were conspicuous in the ovariectomized rats treated with oestrogen but less so in the orchidectomized rats treated with oestrogen even after the long-term administration of female sex hormones. Vaginal smears taken immediately after anaesthesia in the ovariectomized rats treated with oestrogen were

${ }^{1}$ Koch-Light Laboratories Ltd

${ }^{2}$ May and Baker Ltd

\begin{tabular}{|c|c|c|c|c|c|c|c|}
\hline \multicolumn{4}{|c|}{ Castrated Male Rats } & \multicolumn{4}{|c|}{ Ovariectomized Female Rats } \\
\hline \multirow{2}{*}{$\begin{array}{l}\text { Normal } \\
\text { (4 rats) }\end{array}$} & \multirow{2}{*}{$\begin{array}{l}\text { Untreated } \\
\text { (4 rats) }\end{array}$} & \multicolumn{2}{|c|}{ Treated with B-oestradiol } & \multirow{2}{*}{$\begin{array}{l}\text { Untreated } \\
(4 \text { rats })\end{array}$} & \multirow{2}{*}{$\begin{array}{l}\text { Treated with } \\
\text { B-oestradiol (4 rats) }\end{array}$} & \multirow{2}{*}{$\begin{array}{l}\text { Treated with } \\
\text { Progesterone ( } 4 \text { rats) }\end{array}$} & \multirow{2}{*}{$\begin{array}{l}\text { Treated with } \\
\text { Testosterone (4 rats) }\end{array}$} \\
\hline & & $\begin{array}{l}\text { Short-term } \\
\text { (4 rats) }\end{array}$ & $\begin{array}{l}\text { Long-term } \\
(5 \text { rats })\end{array}$ & & & & \\
\hline $\begin{array}{r}5 \cdot 0 \\
13 \cdot 1 \\
2 \cdot 6 \\
4 \cdot 4\end{array}$ & $\begin{array}{l}44 \cdot 4 \\
89 \cdot 6 \\
61 \cdot 1 \\
58 \cdot 1\end{array}$ & $\begin{array}{l}95 \cdot 1 \\
60 \cdot 5 \\
44 \cdot 6 \\
57 \cdot 1\end{array}$ & $\begin{array}{r}87.0 \\
204.1 \\
408.4 \\
93 \cdot 8 \\
380 \cdot 4\end{array}$ & $\begin{array}{l}31 \cdot 8 \\
40 \cdot 6 \\
31 \cdot 6 \\
52 \cdot 6\end{array}$ & $\begin{array}{r}85 \cdot 1 \\
104 \cdot 2 \\
133 \cdot 3 \\
72 \cdot 2\end{array}$ & $\begin{array}{l}45 \cdot 8 \\
64 \cdot 2 \\
27 \cdot 5 \\
35 \cdot 1\end{array}$ & $\begin{array}{l}40 \cdot 0 \\
95 \cdot 2 \\
36 \cdot 4 \\
18 \cdot 9\end{array}$ \\
\hline $\begin{array}{l}\text { Mean } 6 \cdot 3 \\
\pm \text { SD } 5 \cdot 2\end{array}$ & $\begin{array}{l}63 \cdot 5 \\
22 \cdot 6\end{array}$ & $\begin{array}{l}64 \cdot 3 \\
25 \cdot 2\end{array}$ & $\begin{array}{l}234 \cdot 7 \\
146 \cdot 1\end{array}$ & $\begin{array}{l}39 \cdot 1 \\
10 \cdot 5\end{array}$ & $\begin{array}{l}98 \cdot 7 \\
30.5\end{array}$ & $\begin{array}{l}43 \cdot 1 \\
14 \cdot 5\end{array}$ & $\begin{array}{l}47 \cdot 6 \\
38 \cdot 1\end{array}$ \\
\hline
\end{tabular}

Table I Dose of carbachol ( $(n g / 100 \mathrm{~g}$ body weight) for a unit $\mathrm{pH}$ change $(\Delta \mathrm{pH}=1)$ of rat gastric effluent fuid 


\begin{tabular}{|c|c|c|c|c|c|c|c|}
\hline \multicolumn{4}{|c|}{ Castrated Male Rats } & \multicolumn{4}{|c|}{ Ovariectomized Female Rats } \\
\hline \multirow{2}{*}{$\begin{array}{l}\text { Normal } \\
\text { (4 rats) }\end{array}$} & \multirow{2}{*}{$\begin{array}{l}\text { Untreated } \\
(5 \text { rats })\end{array}$} & \multicolumn{2}{|c|}{ Treated with B-oestradiol } & \multirow{2}{*}{$\begin{array}{l}\text { Untreated } \\
(4 \text { rats })\end{array}$} & \multirow{2}{*}{$\begin{array}{l}\text { Treated with } \\
\text { B-oestradiol (5 rats) }\end{array}$} & \multirow{2}{*}{$\begin{array}{l}\text { Treated with } \\
\text { Progesterone ( } 5 \text { rats })\end{array}$} & \multirow{2}{*}{$\begin{array}{l}\text { Treated with } \\
\text { Testosterone ( } 5 \text { rats) }\end{array}$} \\
\hline & & $\begin{array}{l}\text { Short-term } \\
\text { (5 rats) }\end{array}$ & $\begin{array}{l}\text { Long-term } \\
(5 \text { rats })\end{array}$ & & & & \\
\hline $\begin{array}{r}19 \cdot 6 \\
7 \cdot 3 \\
26 \cdot 3 \\
6 \cdot 5\end{array}$ & $\begin{array}{l}20 \cdot 8 \\
32 \cdot 8 \\
32 \cdot 2 \\
11 \cdot 3 \\
16 \cdot 1\end{array}$ & $\begin{array}{l}11 \cdot 8 \\
22 \cdot 8 \\
94.6 \\
20 \cdot 0 \\
46.2\end{array}$ & $\begin{array}{l}34 \cdot 1 \\
88 \cdot 8 \\
48 \cdot 9 \\
50 \cdot 0 \\
63 \cdot 8\end{array}$ & $\begin{array}{l}29 \cdot 4 \\
13 \cdot 4 \\
18 \cdot 1 \\
22 \cdot 1\end{array}$ & $\begin{array}{l}47 \cdot 9 \\
99 \cdot 1 \\
52 \cdot 4 \\
97 \cdot 6 \\
61 \cdot 1\end{array}$ & $\begin{array}{l}26 \cdot 3 \\
17 \cdot 9 \\
12 \cdot 5 \\
18 \cdot 1 \\
14 \cdot 6\end{array}$ & $\begin{array}{r}8 \cdot 5 \\
9 \cdot 3 \\
14 \cdot 1 \\
12 \cdot 3 \\
16 \cdot 0\end{array}$ \\
\hline $\begin{array}{l}\text { Mean } 14.9 \\
\pm \text { SD } 9.9\end{array}$ & $\begin{array}{r}22 \cdot 6 \\
9 \cdot 8\end{array}$ & $\begin{array}{l}39 \cdot 1 \\
37 \cdot 7\end{array}$ & $\begin{array}{l}57 \cdot 1 \\
24 \cdot 9\end{array}$ & $\begin{array}{r}20 \cdot 7 \\
4 \cdot 0\end{array}$ & $\begin{array}{l}71 \cdot 4 \\
23 \cdot 3\end{array}$ & $\begin{array}{r}17 \cdot 9 \\
6 \cdot 3\end{array}$ & $\begin{array}{r}12 \cdot 0 \\
3 \cdot 4\end{array}$ \\
\hline
\end{tabular}

Table II Dose of histamine $(\mu g / 100 \mathrm{~g}$ body weight $)$ for a unit $\mathrm{pH}$ change $(\Delta \mathrm{p} H=1)$ of rat gastric effluent fluid

\begin{tabular}{|c|c|c|c|c|c|c|c|}
\hline \multicolumn{4}{|c|}{ Castrated Male Rats } & \multicolumn{4}{|c|}{ Ovariectomized Female Rats } \\
\hline \multirow{2}{*}{$\begin{array}{l}\text { Normal } \\
\text { (6 rats) }\end{array}$} & \multirow{2}{*}{$\begin{array}{l}\text { Untreated } \\
\text { (6 rats) }\end{array}$} & \multicolumn{2}{|c|}{ Treated with B-oestradiol } & \multirow{2}{*}{$\begin{array}{l}\text { Untreated } \\
(8 \text { rats })\end{array}$} & \multirow{2}{*}{$\begin{array}{l}\text { Treated with } \\
\text { B-oestradiol (5 rats) }\end{array}$} & \multirow{2}{*}{$\begin{array}{l}\text { Treated with } \\
\text { Progesterone ( } 5 \text { rats })\end{array}$} & \multirow{2}{*}{$\begin{array}{l}\text { Treated with } \\
\text { Testosterone ( } 4 \text { rats) }\end{array}$} \\
\hline & & $\begin{array}{l}\text { Short-term } \\
\text { (4 rats) }\end{array}$ & $\begin{array}{l}\text { Long-term } \\
(5 \text { rats })\end{array}$ & & & & \\
\hline $\begin{array}{l}0.6 \\
0.4 \\
1.6 \\
1.2 \\
0.2 \\
1.8\end{array}$ & $\begin{array}{l}2.6 \\
1.8 \\
2.8 \\
1.4 \\
1.6 \\
2.2\end{array}$ & $\begin{array}{l}0.8 \\
2.0 \\
0.5 \\
3 \cdot 2\end{array}$ & $\begin{array}{r}4.9 \\
8.5 \\
5.3 \\
13.4 \\
3.4\end{array}$ & $\begin{array}{l}0.7 \\
0.9 \\
5.2 \\
2.3 \\
5.8 \\
1 \cdot 1 \\
0.3 \\
0.5\end{array}$ & $\begin{array}{r}4.0 \\
10.6 \\
3.0 \\
8.0 \\
3.6\end{array}$ & $\begin{array}{l}1 \cdot 5 \\
2 \cdot 8 \\
9 \cdot 5 \\
6 \cdot 2 \\
2 \cdot 4\end{array}$ & $\begin{array}{l}3.0 \\
5.5 \\
6.0 \\
6.8\end{array}$ \\
\hline $\begin{array}{l}\text { Mean } 0.97 \\
\pm \text { SD } 0.65\end{array}$ & $\begin{array}{l}2 \cdot 1 \\
0 \cdot 57\end{array}$ & $\begin{array}{l}1 \cdot 62 \\
1 \cdot 35\end{array}$ & $\begin{array}{l}7 \cdot 1 \\
4 \cdot 6\end{array}$ & $\begin{array}{l}2 \cdot 1 \\
1 \cdot 9\end{array}$ & $\begin{array}{l}5 \cdot 8 \\
3 \cdot 5\end{array}$ & $\begin{array}{l}4 \cdot 5 \\
3 \cdot 6\end{array}$ & $\begin{array}{l}5 \cdot 3 \\
1 \cdot 9\end{array}$ \\
\hline
\end{tabular}

Table III Dose of gastrin (units/100 $\mathrm{g}$ body weight) for unit $\mathrm{pH}$ change $(\Delta \mathrm{p} H=1)$ of rat gastric effluent fluid

examined under the microscope to establish the presence of oestrus in the rats.

\section{Results}

RESPONSE TO GASTRIN AND CARBACHOL

Acid gastric secretory responses to gastrin and carbachol began within two to three minutes after the completion of the intravenous administration of the secretagogues. The responses followed a gradual decline in the $p \mathrm{H}$ of the gastric effluent and reached the maximum within 12 to 15 minutes. This was followed by a gradual recovery until the $p \mathrm{H}$ of the gastric effluent returned to its original level at the end of 30 to 40 minutes.

\section{RESPONSE TO HISTAMINE}

Acid gastric secretory responses to the intravenous administration of histamine started after a latency period of five to seven minutes and reached their peaks within 25 to 30 minutes, followed by a recovery of the $p H$ of the gastric effluent to its orginal level within 40 to 50 minutes. In some cases, the peak was not reached until 30 to 40 minutes followed by recovery of the gastric effluent $p \mathrm{H}$ to its original baseline in one hour.

Tables I, II, and III show the results of the effects of the different secretagogues, namely, carbachol, histamine, and gastrin, on acid secretions in normal male and female rats, castrated male rats, castrated rats treated with 17Boestradiol (short- and long-term treatments), ovariectomized rats treated with $17 \mathrm{~B}$-oestradiol (short-term treatment), ovariectomized rats treated with testosterone, and ovariectomized rats treated with progesterone.

\section{CASTRATED ANIMALS}

Bilateral castration of the male rats significantly reduced acid gastric secretory responses to carbachol $(0.002<\mathrm{P}<0.01)$, but not to histamine $(0.2<\mathrm{P}<0.3)$.

When the castrated animals were given short-term treatment with 17B-oestradiol, there was a reduction in acid gastric secretion which was below statistical significance in rats given carbachol $(P=0.9)$, histamine $(0.3<P<0.4)$, or gastrin $(0.5<\mathrm{P}<0.6)$. Long-term treatment of castrated animals with 17B-oestradiol significantly reduced acid gastric secretion induced with histamine $(0.01<\mathrm{P}<0.02)$ and with gastrin $(0.02<P<0.05)$ but not with carbachol $(0.05<\mathrm{P}<0.01)$. 
OVARIECTOMIZED ANIMALS

Ovariectomized rats treated with 17B-oestradiol (short-term treatment) showed a statistically significant reduction in acid gastric secretion induced with all the secretagogues: carbachol $(0.01<\mathrm{P}<0.02)$, histamine $(0.002<\mathrm{P}<$ $0.01)$, and gastrin $(P=0.05)$. When ovariectomized rats were treated with testosterone, the acid gastric secretory responses were inconsistent as recorded from experiments with the different secretagogues. In animals given gastrin or histamine there was a reduction in acid gastric secretion which was of statistical significance with gastrin $(0.02<\mathrm{P}<0.05)$ but not with histamine $(0.05<\mathrm{P}<0.1)$. In animals given carbachol to induce acid secretion there was an increase in acid gastric secretion which was, however, not statistically significant $(P=0 \cdot 6)$.

In ovariectomized rats pretreated with progesterone, the acid gastric secretion responses to the secretagogues under study did not differ significantly from those in the ovariectomized untreated rats. There was a reduction in the acid gastric secretory response in animals given gastrin $(P=0.2)$ or carbachol $(P=0.7)$ while there was a rise in the acid secretory response in rats with histamine $(P=0 \cdot 5)$.

\section{Discussion}

The acid gastric secretory responses to intravenous injections of gastrin and histamine in the castrated rats treated with hormones and the normal rats confirm the findings of Ghosh and Schild (1958) for histamine and of Amure and Ginsburg (1964) for both histamine and gastrin. It appears that castration alone, or combined with sex hormone treatment, does not alter the characteristics of the pattern of the responses to histamine and gastrin even when the degree of acid gastric secretion was known. Responses to carbachol show similar characteristics in the pattern of secretion as are seen with the gastrininduced acid secretory responses.

The inhibitory influence of castration on acid gastric secretion appears in the male rats from the results obtained to be dependent on the length of time elapsing after gonadectomy before testing for the acid gastric secretory responses. Inhibition of acid secretion was of statistical significance in two groups of castrated male rats. One of the groups was stimulated with gastrin nine to 24 days after gonadectomy and the other group was stimulated with carbachol seven to 12 days after gonadectomy. The third group of castrated male rats given histamine four to six days after gonadectomy gave a statistically insignificant reduction in acid gastric secretory response. This finding seems to indicate a gradual decline in the blood concentration of a principle originating from the testes which is beneficial to gastric secretion, and the decline seems to be sufficient for the inhibition of gastric secretion as from the seventh day after gonadectomy. In a previous report on liver enzymic activity, the effects of castration in male rats were prevented by the administration of testosterone (Hagen and Troop, 1960). It is thus reasonable to attribute the inhibition of gastric secretion after orchidectomy to a fall in testosterone blood concentration. Elevating the blood level of testosterone to a fairly high level would therefore be expected to produce increased gastric acid secretory activity. This hypothesis was tested by administering testosterone to ovariectomized rats. The results showed that there was no increase in gastric acid secretory response, and there was a striking reduction in acid gastric response in some rats while in others there was no change.

Oestrogen inhibition of acid gastric secretion is evident from the results. A higher level of blood oestrogen concentration was required for this inhibitory effect in the castrated male rats as shown by the ineffectiveness of short-term oestrogen treatment in them, in contrast to the castrated female rats. The long-term treatment with oestrogen was effective in significantly depressing gastric secretory activity in the castrated male rats given histamine or gastrin while a longer duration of treatment was indicated by the data from the carbachol-stimulated rats. This sex difference in the acid gastric secretory responses to oestrogen treatment confirms a previous observation in normal cats by Ojha and Wood (1950) and perhaps constitutes indirect evidence of a higher level of gastric secretory activity in the male rats as compared with the female animals.

Some previous findings capable of explaining the reduced acid gastric secretory responses after oestrogen administration seem to be of value. Sawyer and Everett (1946) reported an elevation of serum cholinesterase in castrated rats after oestrogen administration. Babkin (1944) suggested the role of acetylcholine in the production of acid gastric juice, and that an increased serum cholinesterase level would be expected to inhibit gastric secretion.

An increased histaminase concentration was observed in the stomach of pregnant rats (Lozzio et al, 1961) but this change in enzyme concentration could not, according to these authors, explain the concurrent inhibition of gastric secretion since the histaminase level changed even in rats with unaltered gastric secretion.

The present findings do not implicate changes in the histamine-forming capacity of the rat gastric mucosa in the gastric secretory changes after hormone treatment in view of the similar changes in gastric secretory responses with histamine, gastrin, and carbachol, while an earlier report by Kahlson, Rosengren, Svahn, and Thunberg (1964) showed increases in the histamineforming capacity of the rat gastric mucosa during 
gastric secretion induced by refeeding fasted rats with gastrin but not with histamine.

Provided sufficient progesterone had been administered in our experiments, the findings here contradict those of Parbhoo and Johnston (1966) who observed a significant reduction in the histamine-stimulated gastric secretion after 17 hydroxyprogesterone coproate in humans.

From the available data in this work it is clear that of all of the sex hormones used, only oestrogen had a significant and conclusive effect on acid gastric secretion. The oestrogenic inhibition of acid gastric secretion suggests that the beneficial effect of oestrogen on healing of peptic ulcers in humans might in part be due to this effect. Moreover oestrogens are thereby implicated in the depression of gastric secretion occurring during pregnancy in some species of animals.

\section{References}

Amure, B. O., and Ginsburg, M. (1964). Inhibitors of histamine catabolism and the action of gastrin in the rat. Brit. J. Pharmacol., 23, 476-485.

Artz, F. (1930). Further observations on the gastric juice in pregnancy. Amer. J. Obstet. Gynec., 20, 382-385.

Babkin, B. P. (1944). Secretory Mechanisms of the Digestive Glands P. 375. Hoeber, New York.'

Baron, J. H. (1963). Studies of basal and peak acid output with an augmented histamine test. Gut, 4, 136-144.

Clark, D. H. (1957). Gastric acid secretion in dogs during pregnancy and lectation. Scot. Med. J., 2, 392-395.

Culmer, C. U., Atkinson, A. J., and Ivy, A. C. (1939). Depression of gastric secretion by the anterior pituitary-like fraction of pregnancy urine. Endocrinology, 24, 631-637.

Doll, R., Hill, I. D., and Hutton, C. F. (1965). Treatment of gastric ulcer with carbenoxolone sodium and oestrogens. Gut, 6, 19-24.
Ghosh, M. N. (1959). Inhibition of acid gastric secretion in the rat by chorionic gonadotrophin. J. Physiol. (Lond.), 147, 585-590.

Ghosh, M. N., and Schild, H. O. (1958). Continuous recording of acid gastric secretion in the rat. Brit. J. Pharmacol, 13, 54-61.

Hagen, A. A., and Troop, R. C. (1960). Influence of age, sex and adrenocortical status on hepatic reduction of cortisone in vitro. Endocrinology, 67, 194-203.

Hunt, J. N., and Murray, F. A. (1958). Gastric function in pregnancy. J. Obstet. Gynaec. Brit. Emp., 65, 78-83.

Kahlson, G., Rosengren, E., Svahn, D., and Thunberg, R. (1964). Mobilization and formation of histamine in the gastric mucosa as related to acid secretion. J. Physiol. (Lond.), $174,400-416$.

Kaufmann, H. J., and Spiro, H. M. (1968). Estrogens and Gastric Secretion. Gastroenterology, 54, 913-917.

Labate, J. S. (1939). The effect of pregnancy on gastric secretion. Amer. J. Obstet. Gynec., 38, 650-653.

Lozzio, B. B., Gagliardi, O. P., Biempica, L., and Royer, M. (1961). Effects of pregnancy on gastric secretion in rats. Gastroenterology, 41, 126-128.

McCarthy, J. D., Evans, S. O., and Dragstedt, L. R. (1954). Gastric secretion in dogs during pregnancy and lactation. Gastroenterology, 27, 275-280.

MacDonald, I.(1956). Gastric activity during the menstrual cycle. Gastroenterology, 30, 602-607.

Murray, F. A., Erskine, J. P., and Fielding, J. (1957). Gastric secretion in pregnancy. J. Obstet. Gynaec. Brit. Cwlth, 64, 373-381.

Ojha, K. N., and Wood, D. R. (1950). The inhibitory effect of stilboesterol on gastric secretion in cats. Brit. J. Pharmacol., 5:389-394.

Parbhoo, S. P., and Johnston, I. D. A. (1966). Effects of oestrogens and progestogens on gastric secretion in patients with duodenal ulcer. Gut, 7, 612-618.

Sawyer, C. H., and Everett, J. W. (1946). Effects of various hormonal conditions in the intact rat on the synthesis of serum cholinesterase. Endocrinology, 39, 307-322.

Strauss, M. B., and Castle, W. B. (1932). Studies of anemia in pregnancy. 1 Gastric secretion in pregnancy and the puerperium. Amer. J. med. Sci., 184, 655-662.

Truelove, S. C. (1960). Stilboestrol, phenobarbitone and diet in chronic duodenal ulcer. A factorial therapeutic trial. Brit. med. J., 2, 559-566.

Way, S. (1945). Relation between gastric acidity and the anteriorpituitary-like, hormone content of urine in pregnant women. Brit. med. J., 2, 182-184. 